\title{
Implmentasi Program Diklat Struktural Pada Kantor Badan Kepegawaian dan Diklat Dalam Rangka Meningkatkan SDM Pegawai Negeri Kabupaten Sorong
}

\author{
Saiful Ichwan \\ FISIP, Universitas Muhammadiyah Sorong, Indonesia \\ *Korespondensi: saifulichwan1@gmail.com
}

\begin{abstract}
Penelitian ini dilakukan dengan tujuan untuk untuk mengetahui Bagaimana Implementasi Program Diklat Struktural Pada Kantor Badan Kepegawaian dan Diklat dalam rangka meningkatkan SDM Pegawai Negeri Kabupaten Sorong. Metode penelitian yang digunakan, adalah dengan pendekatan deskriptif kualitatif. Dengan teknik pengumpulan data melalui observasi lapangan, dokumentasi, dan wawancara yang ditujukan kepada para informan dari kalangan pegawai pada Badan Kepegawaian dan Diklat Kabupaten Sorong. Hasil penelitian menunjukkan bahwa pelaksanaan Diklat Struktural telah terlaksana dengan cukup baik dengan adanya metode dan kurikulum terbaru dari Lembaga Administrasi Negara yang dipandang lebih progresif dalam membekali para pejabat atau calon pejabat yang berstatus sebagai peserta diklat dengan wawasan, pengetahuan dan berbagai keterampilan dalam menunjang pekerjaan para pejabat atau calon pejabat pemerintahan sesuai dengan profesi dan uraian tugas jabatanya, namun terdapat beberapa faktor penghambat yakni kurang memadainya sarana dan prasarana pendukung serta yang terpenting adalah Kualitas dan jumlah tenaga widyaiswara yang masih sangat terbatas. Adapun upaya yang yang dilakukan Badan Kepegawaian dan Diklat Kabupaten Sorong meliputi upaya yang bersifat Prosedur dann teknis. Upaya Prosedural berkaitan dengan proses input dan output program kerja Badan Kepegawaian dan Diklat sementara Upaya tekniks berkaitan dengan kebutuhan-kebutuhan terkait dengan penyelenggaraan program kerja Serta kegiatan Kediklatan.
\end{abstract}

Kata kunci: Implementasi, Pendidikan dan Pelatihan, SDM

\begin{abstract}
ABSTRAK
This research was conducted with the aim to find out how the Implementation of Structural Training Program in the Office of Personnel and Training Agency in order to improve the Human Resources of Sorong Regency Civil Servants. The research method used, is a qualitative descriptive approach. Using data collection techniques through field observations, documentation, and interviews aimed at informants from the staff at the Sorong Regency Personnel and Training Agency. The results showed that the implementation of Structural Training had been carried out quite well with the latest methods and curricula of the State Administration Institute which were considered more progressive in equipping officials or prospective officials who were training participants with insight, knowledge and various skills in supporting the work of officials or prospective government officials in accordance with the profession and job descriptions, but there are several inhibiting factors, namely inadequate supporting facilities and infrastructure and the most important is the quality and the number of lecturers who are still very limited. The efforts made by the Sorong Regency Personnel and Training Agency include efforts that are procedural and technical in nature. Procedural efforts related to the process of input and output of the work program of the Personnel and Training Agency while technical efforts related to the needs associated with the implementation of work programs and education activities.
\end{abstract}

Keywords: Implementation, Education and Training, Human Resources 


\section{PENDAHULUAN}

Dalam rangka meningkatkan kinerja serta kualitas Sumber Daya Manusia (SDM), Aparatur Sipil Negara (ASN) dituntut agar mampu mendukung sistem administrasi negara dalam menjalankan fungsi utama yaitu fungsi penyelenggaraan pemerintahan, fungsi pembangunan dan fungsi pelayanan masyarakat. Implementasi beberapa ketentuan dan fungsi utama ini diselenggarakan oleh pemerintah, mulai dari tingkat pusat sampai pemerintah propinsi dan pemerintah Kota / Kabupaten. Sebagai ujung tombak pelaksanaan ketiga fungsi ini adalah Pemerintah Kota/Kabupaten yang secara nyata berhadapan langsung dengan masyarakat. Sedangkan sampai saat ini pembinaan aparatur Pemerintah Kota/Kabupaten masih tergolong minim dilakukan oleh pemerintah dengan alasan keterbatasan dana dan alasan tekhnis lainya, khususnya yang menyangkut masalah pendidikan dan pelatihan.

Setiap organisasi baik swasta maupun pemerintah yang berkeinginan untuk maju, tentunya mempunyai suatu kegiatan yang dapat membantu para pegawai untuk mendapatkan suatu keterampilan yang diperlukan oleh pegawai dalam mencapai tujuan organisasi. Menurut Ambar (2009:219), hubungan pendidikan dan pelatihan dengan kinerja merupakan cara yang dilakukan untuk proses dimana pegawai diberi informasi dan pengetahuan tentang kepegawaian, organisasi dan harapan-harapan untuk mencapai performance tertentu. Pendidikan dan pelatihan juga bermanfaat untuk meningkatkan kemampuan dan kecakapan, terutama pada masa sekarang dan yang akan datang. Selain itu juga pendidikan dan pelatihan bermanfaat untuk meningkatkan keahlian dan keterampilan yang disesuaikan dengan bidang pekerjaannya masingmasing. Menurut Sastrohadiwiryo (2001:206-207), pada kenyataannya setiap pegawai memerlukan pendidikan dan pelatihan untuk melaksanakan tugas dan pekerjaannya. Baik pegawai baru memerlukan pendidikan dan pelatihan awal (preservice training) maupun pegawai lama (in service training) memerlukan tambahan kualitas dalam bekerja salah satunya adalah melalui pendidikan dan pelatihan tambahan. Selain itu juga pendidikan dan pelatihan membantu manajemen para pegawai dalam menentukan tujuan yang ingin dicapai dan dalam pengembangan administrasi.

Pengembangan profesionalisme Aparatur Sipil Negara (ASN) merupakan salah satu agenda nasional dalam upaya pendayagunaan aparatur pemerintah. Pegawai Negeri Sipil yang professional 
diharapkan dapat mendukung kelancaraan pelaksanaan tugas penyelenggaran pemerintahan dan pembangunan. Sejalan dengan tuntutan profesionalisme aparatur, badan pendidikan dan pelatihan sebagai unsur penunjang di Badan Kepegawaian dan Diklat Kabupaten Sorong, di tuntut dapat menyiapkan aparatur yang professional. Penyelenggaraan itu sendiri terdiri dari berbagai kegiatan pendidikan dan pelatihan baik teknis, fungsional maupun struktural.

Suatu program pelatihan pasti telah banyak menghabiskan waktu, energi, serta biaya untuk pelaksanaannya, oleh karena itu setelah mengikuti proses diklat maka peningkatan kualitas peserta diklat sangat harus diketahui dan apakah peserta peserta diklat berprestasi dalam bekerja di instansi tempat ia bekerja. Hal tersebut perlu dilakukan agar program pelatihan tidak siasia. Pendidikan apa pun baik individu, kelompok maupun masyarakat.

Berbicara mengenai tugas pokok dan fungsi sama halnya berbicara mengenai peran diklat yaitu bahwa fungsi diklat yang di harapkan dapat berjalan dengan baik. Jika diklat menjalankan perannya dengan baik maka ia akan mendapatkan akreditasi atau citra yang baik dalam memberikan pendidikan dan pelatihan pegawai. Namun pada kenyataannya ada beberapa masalah yang di hadapi yaitu seperti halnya fakta- fakta di lapangan menunjukkan bahwa kurikulum, program, dan materi pelajaran baik diklat pimpinan, fungsional, dan teknis lebih menonjolkan ranah koginitif (melihat, mengingat, dan berfikir tentang informasi) dan psikomotor (hubungan dengan aktivitas fisik yang berkaitan dengan proses mental dan psikologi) ketimbang ranah afektif (mengenai sikap, minat, emosi, minat hidup dan operasiasi siswa). Pendidikan dan pelatihan dengan berbagai tingkatan dan jenisnya bagi setiap pegawai merupakan suatu keharusan agar memiliki integritas sikap dan kompetensi dalam melaksanakan tugasnya.

Pendidikan dan pelatihan (Diklat) merupakan proses penyelenggaraan belajar mengajar dalam rangka peningkatan kemampuan pegawai yang meliputi pengetahuan, keterampilan, sikap dan perilaku yang diperluhkan dalam melaksanakan tugasnya, Suradinata (2003:211). Hal-hal lain juga perlu di perhatikan pendidikan dan pelatihan (Diklat) adalah kebijaksanaan mengenai "prioritas program dalam pendidikan dan pelatihan (Diklat)" agar dapat meningkatkan dan memperbaiki kelemahan, serta meningkatkan kualitas kinerja pegawai negeri sipil, yang professional sesuai bidang tugasnya dan memiliki etos kerja yang disiplin, efesien, 
efektif, kreatif produktif, serta bertanggunjawab.

\section{METODE}

Jenis penelitian yang digunakan dalam penelitian ini adalah metode penelitian kualitatif. Dalam penelitian ini populasi yang di maksud adalah seluruh pegawai negeri Kabupaten Sorong. Sumber data yang tidak tepat, mengakibatkan data yang terkumpul menjadi tidak relevan yang dapat menimbulkan kekeliruan dalam menarik kesimpulan. Dari jumlah keseluruhan pegawai negeri Kabupaten Sorong penulis mengambil 6 orang pegawai negeri yang berdinas pada kantor Badan Kepegawaian dan Diklat Daerah Kabupaten Sorong. Teknik pengumpulan data dengan menggunakan data primer dan sekunder. Teknik analisis data dilakukan dengan cara kualitatif, dimana data yang diperoleh dari berbagai sumber yang berhubungan dengan tujuan penelitian terus di olah sejak awal dengan cara sebagai berikut: 1) Reduksi Data (Data Reduction), 2) Penyajian Data (Data Display), 3) Kesimpulan (Conclusion drawing/verfication).

\section{HASIL DAN PEMBAHASAN}

\section{Implementasi Program Diklat Struktural Pada Kantor Badan Kepegawaian dan Diklat Dalam Rangka Meningkatkan SDM Pegawai Negeri Kabupaten Sorong.}

Implementasi Program Diklat Struktural pada Kantor Badan Kepegawaian dan Diklat Kabupaten Sorong dirasakan cukup baik sebagaimana hasil wawancara peneliti dengan informan pertama yakni Bapak H.R selaku Kepala Badan Kepegawaian dan Diklat Daerah Kabupaten Sorong dengan penjelasan sebagaimana berikut:

"Sehubungan dengan Implementasi Program Diklat Struktural tersebut sebagaimana diamantkan dalam UndangUndang Nomor 5 Tahun 2014 tentang pengembangan kompetensi Pegawai Negeri Sipil melalui program pendidikan dan pelatihan. Dengan adanya program pendidikan dan pelatihan struktural atau biasa disebut Diklat Kepemimpinan yang telah dilaksanakan di Badan Diklat kami, dimana dalam pelaksanaan proses diklat ini meskipun dengan sumberdaya modal dan sumberdaya lainya yang serba terbatas namun kami rasakan sudah berjalan dengan baik dalam membekali para peserta diklat dengan wawasan dan pengetahuan sesuai profesi dan tugas jabatan yang diemban oleh pejabat atau calon pejabat pemerintahan. Melalui Diklat Kepemimpinan ini kami harapkan dapat terbangun sumberdaya manusia, moral, kejujuran, sikap, serta memperkuat profesionalisme kerja pejabat pemerintahan yang disiapkan sebagai pemimpin masa depan".

(Hasil wawancara, 05 November 2018)

Berdasarkan hasil wawancara peneliti dengan informan pertama dapat disimpulkan bahwa Implementasi Program Diklat Struktural adalah berlandaskan amanah Undang-Undang Nomor 5 tahun 2014 tentang pengembangan kompetensi Pegawai Negeri Sipil melalui proses 
Pendidikan dan Pelatihan atau secara singkat disebut dengan Diklat.

Senada dengan hasil wawancara dari informan pertama yang kemudian ditegaskan kembali melalui hasil wawancara peneliti terhadap informan kedua, yakni Ibu F.M selaku Kepala Bidang Diklat yangmana hasil wawancara dengan informan kedua dapat peneliti paparkan sebagai berikut : "Diklat Struktural atau Diklatpim atau Diklat Penjenjangan Karir adalah Program pendidikan dan pelatihan yang bertujuan untuk menanamkan jiwa kepemimpinan, meningkatkan dan mengembangkan mutu, keahlian, kemampuan, ketrampilan, dan yang terpenting adalah sikap Pegawai Negeri Sipil agar dapat melaksanakan tugas dan tanggungjawab yang dipercayakan kepadanya dengan baik. Diklatpim ini diadakan untuk memenuhi persyaratan kompetensi kepemimpinan aparatur pemerintah sesuai dengan jenjang eselon jabatan struktural tertentu.

Sesuai dengan Peraturan Pemerintah Nomor 13 Tahun 2002 tentang perubahan Peraturan Pemerintah Nomor 100 Tahun 2000 tentang Pengangkatan PNS dalam Jabatan Struktural, yang mana dengan adanya peraturan ini ditekankan bagi setiap Pegawai Negeri Sipil yang akan atau telah menduduki jabatan struktural wajib atau harus mengikuti dan lulus ujian pendidikan dan pelatihan kepemimpinan sesuai dengan kompetensi yang ditetapkan untuk jabatan tersebut . Adapun Program Diklat Pim yang telah kami selenggarakan di kantor kami hanya Diklat Pim III dan Diklat Pim IV saja yang mengacu pada kurikulum terbaru Lembaga Administrasi Negara yang menurut kami semakin visioner dan lebih progresif dalam meningkatkan pengetahuan para peserta diklat". (Hasil wawancara, 07 November 2018)

Berdasarkan hasil wawancara dengan informan kedua dapat peneliti simpulkan bahwa, Diklat Struktural atau Diklatpim atau Diklat Penjenjangan Karir adalah Program pendidikan dan pelatihan yang bukan saja bertujuan untuk meningkatkan SDM terutama sikap Pegawai Negeri Sipil agar dapat menjalankan tugas jabatan dengan penuh tanggungjawab, akan tetapi lebih dari itu Diklatpim tersebut merupakan sebuah prosedur sekaligus persyaratan kompetensi bagi setiap Pegawai Negeri Sipil yang harus dilalui serta dinyatakan lulus dalam mengikuti ujian pendidikan dan pelatihan kepemimpinan tersebut guna dipersiapkan untuk menduduki jabatan tertentu sesuai dengan jenjang karir dan bidang tugasnya. Sementara itu hasil wawancara peneliti dengan informan ketiga yakni Bapak A.T selaku Kasubid Pendidikan, Pelatihan dan Sertifikasi Jabatan yangmana hasil 
wawancara dengan informan ketiga ini dapat diuraikan sebagaimana berikut : "Menurut saya program Diklat Struktural atau Diklat Kepemimpinan baik itu Pim III yang disebut juga Diklat Administrator dan Pim IV bagi Kasubid semakin berbobot dengan adanya kurikulum terbaru dari Lembaga Administrasi Negara tentang metode dan teknis pelaksanaan Pendidikan dan pelatihan Kepemimpinan. Kalau dulu dibawah tahun 2014 peserta diklatpim mengikuti proses diklat selama dua bulan lebih dan diakhiri dengan ujian selama seminggu, namun sekarang proses diklat pim dilaksanakan dengan tiga tahap yakni para peserta diklat pim dididik selama sebulan lebih, tahap selanjutnya para peserta diklat diserahkan kembali ke tiaptiap instansi asal tempat mereka berdinas selama dua bulan dimana selama dua bulan itu mereka di tuntut untuk membuat projekprojek perubahan sesuai dengan bidang tugas jabatan mereka pada dinas masing masing. Tahapan proses diklat yang terakhir adalah para peserta diklat ditarik kembali ke tempat pelatihan untuk mengikuti ujian akhir dari proses diklat dimana para peserta diklat diwajibkan untuk mempresentasikan hasil dari proposal Projek-Projek perubahan yang telah dibuatnya. Dengan demikian melalui metode diklat terbaru ini peningkatan SDM peserta diklat membuahkan hasil yang lebih baik". (Hasil wawancara, 09 November 2018). Sesuai dengan hasil wawancara dengan informan ketiga dapat peneliti simpulkan bahwa, Terdapat perbedaan dalam proses pelaksanaan program Diklatpim sebelum tahun 2015 dan proses pelaksanaan program Diklatpim yang diadakan sekarang baik itu Pim III yang disebut juga Diklat Administrator dan Pim IV bagi Kasubid.

Faktor Penghambat Implementasi Program Diklat Struktural Pada Kantor Badan Kepegawaian dan Diklat Dalam Rangka Meningkatkan SDM Pegawai Negeri Kabupaten Sorong.

Berangkat dari tujuan yang ingin dicapai tersebut maka perlu diketahui apa saja faktorfaktor yang menjadi penghambat implementasi program diklat struktural dalamrangka meningkatkan SDM pegawai negeri sipil yang akan diuraikan pada hasil wawancara antara peneliti dengan Bapak C.S selaku Widyaiswara Muda. Adapun hasil wawancara tersebut sebagai berikut: "Menurut saya kalau kita bicara faktor penghambat maka kita harus tahu dulu faktor pendukungnya seperti ketersediaan fasilitator atau Widyaiswara yang cukup, Kurikulumnya bagus dan sarana prasarana diklat yang memadai. Saya pikir dari segi kurikulum sudah bagus sekali namun yang jadi kendala kita disini ketersediaan dan kualitas fasilitator atau Widyaiswara, untuk diketahui bahwa tenaga widyaiswara kita cuma dua orang itupun untuk mengisi satu dua materi diklat saja jadi kalau ada penyelenggaraan diklat mau dan tidak mau kita harus buat permintaan tenaga widyaiswara dari luar daerah 
yang ujung-ujungnya membebani anggaran belum lagi kurang memadainya sarana dan prasarana diklat seperti kelengkapan alat bantu belajar, instalasi internet yang belum ada bagi sekertariat, AC, televisi, dan kulkas yang sepantasnya disiapkan di asrama bagi peserta diklat karena para peserta ini kan para pejabat jadi paling tidak kita harus berikan pelayanan yang baik kepada mereka berupa fasilitas yang layaklah agar peserta diklat betah dan konsen selama proses diklat berlangsung, mungkin itu saja”. (Hasil wawancara, 09 November 2018)

Berdasarkan hasil wawancara peneliti dengan Bapak C.S selaku Widyaiswara Muda dapat disimpulkan bahwa, terdapat berberapa faktor yang menjadi kendala selama proses berlangsungnya diklat di Badan Diklat Kabupaten Sorong pertama adalah kualitas serta kuantitas tenaga fasilitator, seperti kita ketahui bahwa widyaiswara yang berkompeten dan profesional dalam melaksanakan tugasnya tentu akan menguasai dalam mempersiapkan bahan ajar atau materi ajar yang telah disusun sedemikian rupa dalam penerapan metode pengajarannya, strategi atau pendekatan pembelajarannya, serta penerapan multi media pendukung pembelajarannya, pemanfaatan sumber pembelajaran yang menunjang serta mampu melakukan evaluasi hasil belajar secara cermat.

Sementara itu hasil wawancara peneliti dengan informan ketiga yakni Bapak A.T selaku Kasubid Pendidikan, Pelatihan dan Sertifikasi Jabatan yangmana hasil wawancara dengan informan ketiga ini dapat diuraikan sebagaimana berikut : "Menurut yang kami ketahui selama bertugas disini memang ada beberapa hambatan yang menjadi perhatian kami seperti kurangnya kuota tenaga widyaiswara serta terbatasnya sarana dan prasarana diklat baik itu hambatan yang bersifat pra pelaksanaan maupun hambatan dalam proses pelaksanan diklat itu sendiri, dan apa yang menjadi penyebab munculnya hambatan -hambatan tersebut tidak lain adalah karena kurangnya komitmen pemda Kabupaten Sorong dalam menjawab usulan programprogram kami, jika saja pemda dapat mendukung kami dengan anggaran yang cukup maka sudah tentu hambatan-hambatan tersebut dapat teratasi”. (Hasil wawancara, 09 November 2018)

Berdasarkan hasil wawancara peneliti dengan Bapak A.T selaku Kasubid Pendidikan, Pelatihan dan Sertifikasi Jabatan dapat disimpulkan bahwa, terdapat beberapa hambatan yang selama ini menjadi Consern atau perhatian pihak penyelenggara diklat baik itu hambatan sebelum berlangsungnya proses diklat maupun hambatan selama proses diklat berjalan. Diketahui bahwa hambatan-hambatan tersebut terjadi disebabkan oleh kurangnya perhatian Pemerintah Kabupaten Sorong dalam menindaklanjuti usulan-usulan program badan Kepegawaian dan Diklat yang direalisasikan dalam bentuk pengalokasian anggaran yang proporsional guna menunjang terlaksananya seluruh program-program diklat sekaligus mengatasi hambatan-hambatan yang terjadi dalam pelaksanaan proses diklat. 
Selanjutnya hasil wawancara peneliti dengan informan kelima yakni Ibu M. selaku Staf Pengadministrasi Pelatihan sebagaimana berikut : “ Memang ada beberapa hambatan dalam proses pelaksanaan diklat seperti yang sudah kita ketahui seperti sarana dan prasarana yang belum cukup memuaskan dan terbatasnya jumlah tenaga pengajar. Kalau untuk masalah sarana dan prasarana saya rasa bukan hambatan yang berartilah tapi kalau untuk tenaga pengajar ini yang harus betulbetul diperhatikan karena sangat kurang, kita cuma punya 2 orang tenaga pengajar baik widyaiswara Pertama dan Widyaiswara Muda makanya setiap penyelenggaraan diklat baik struktural maupun non struktural konsekwensinya kita mau dan tidak mau harus mengambil tenaga pengajar dari luar lagi akhirnya ujungujungnya anggaran diklat terbebani, makanya kami berharap pihak pemda bisa segera menindaklanjuti masalah ini”. (Hasil wawancara, 09 November 2018).

Berdasarkan hasil wawancara peneliti dengan informan kelima yakni Ibu M. selaku Staf Pengadministrasi Pelatihan dapat peneliti simpulkan bahwa terdapat 2 hambatan yang diketahui selama ini menjadi kendala dalam proses pelaksanaan diklat yakni kurang memadainya sarana dan prasarana diklat serta minimnya jumlah tenaga widyaiswara.

Melalui hasil wawancara dengan beberapa informan terkait permasalahan diatas maka diketahui bahwa terdapat beberapa faktor yang selama ini menjadi penghambat implementasi program diklat struktural pada Kantor Badan Kepegawaian dan Diklat Kabupaten Sorong sebagaimana dirangkum dibawah ini: 1) Adanya berberapa faktor yang menjadi kendala selama proses berlangsungnya diklat Struktural diantaranya ialah terbatasnya jumlah tenaga widya iswara serta kurang memadainya sarana dan prasarana pendukung. 2) Adanya hambatan sebelum berlangsungnya proses diklat maupun hambatan selama proses diklat berjalan disebabkan oleh kurangnya perhatian pemerintah dalam bentuk anggaran guna mendukung usulan-usulan terkait kebutuhan penyelenggaraan diklat. 3) Kurang memadainya sarana dan prasarana diklat tidak memberikan dampak yang berarti bagi proses penyelenggaraan namun untuk masalah tenaga widyaiswara maka dibutuhkan perhatian yang serius oleh pemerintah daerah dalam meningkatkan jumlah dan standar kwalifikasi widyaiswara dimana jumlah dan standar kwalifikasi widyaiswara merupakan unsur yang paling urgen dalam pencapaian tujuan program diklat.

Upaya yang dilakukan Badan Kepegawaian dan Diklat Dalam Rangka meningkatkan SDM Pegawai Negeri Kabupaten Sorong.

Untuk mengetehui Apasaja upaya yang dilakukan Badan Kepegawaian dan Diklat Dalam Rangka meningkatkan SDM Pegawai Negeri Kabupaten Sorong, maka 
peneliti ketahui melalui hasil wawancara dengan informan pertama yakni Bapak H.R selaku Kepala Badan Kepegawaian dan Diklat Daerah Kabupaten Sorong dengan penjelasan sebagaimana berikut: "secara prosedur tentunya pertama-tama kita adakan kajian atau analisis jabatan apakah ada kekosongan atau ada hal-hal lain yang harus dilakukan guna melengkapi kebutuhan kebutuhan terkait formasi jabatan ASN demi meningkatkan pelayanan publik serta kinerja aparatur. Kemudian berdasarkan output dari hasil kajian tersebut kami membuat usulan rencana kerja anggaran tahunan instansi kami, salah satu diantaranya yaitu program kegiatan penyelnggaraan diklat struktural baik diklat pim iii maupun diklat pim iv yang kemudian akan disampaikan dalam rapat pembahasan kerja anggaran tahunan pemerintah kabupaten sorong. Jika usulan kami dijawab barulah kami mengkordinasi kepada tiap-tiap skpd pada kabupaten sorong agar segera mengusulkan pegawai yg akan mengikuti diklat kepemimpinan sesuai dengan spesifikasi jenjang jabatan dan kriteria-kriteria tertentu sebagai prasayarat dalam mengikuti diklatpim dengan jadwal yg ditentukan. Upaya kami selanjutnya sifatnya teknis namun tak kalah penting yakni kami datangkan tenaga widyaiswara yg berkompeten baik dari LAN profinsi, LAN makassar bahkan bila perlu kami datangkan dari lan pusat sebagai pemateri diklat, dan tak lupa kami akan meningkatkan lagi jumlah serta kompetensi tenaga widyaiswara kami yang akan diikutsertakan pada diklat khusus bagi widyaswara yang diselenggarakan di tingkat provinsi maupun di pusat, adapun untuk kesiapan sarana dan prasarana kami rasa cukup". (Hasil wawancara, 05 November 2018)

Berdasarkan hasil wawancara peneliti dengan Bapak H.R selaku Kepala Badan Kepegawaian dan Diklat Daerah Kabupaten Sorong dapat disimpulkan bahwa, upaya yang dilakukan Badan Kepegawaian dan Diklat Dalam Rangka meningkatkan SDM Pegawai Negeri Kabupaten Sorong terdiri dari upaya yang bersifat Prosedural dan Upaya yang bersifat teknis.

Demi mencapai tujuan yang dikehendaki terkait Implementasi Program Diklat Struktural dalam rangka meningkatkan SDM pegawai negeri maka Kepala Badan Kepegawaian dan Diklat Daerah Kabupaten Sorong berkomitmen untuk melakukan berbagai upaya baik Prosedural maupun teknis sebagaimana diringkas dibawah ini: 1) Upaya Prosedural yang meliputi beberapa tahapan yakni analisis kebutuhan aparatur dalam rangka menigkatkan kinerja pelayanan Pegawai Negeri Sipil, selanjutnya hasilnya dituangkan dalam suatu bentuk usulan program kegiatan diantaranya program kegiatan Diklatpim atau Diklat Struktural yang akan diajukan pada rapat kerja pembahasan anggaran tahunan Pemda Kabupaten Sorong untuk disetujui. 2) Upaya yang bersifat Teknis meliputi penyediaan tenaga widyaiswara interlokal, penembahan jumlah tenaga widyaiswara lokal serta peningkatan kompetensi melalui diklat khusus bagi tenaga widyaiswara lokal, dan terkait 
masalah kesiapan sarana dan prasarana pendukung dirasakan cukup baik.

\section{SIMPULAN}

Berdasarkan hasil penelitian mengenai Implementasi Program Diklat Struktural Pada Kantor Badan Kepegawaian dan Diklat Dalam Rangka Meningkatkan SDM Pegawai Negeri Kabupaten Sorong disimpulkan bahwa :

1. Proses pelaksanaan Diklatpim baik PIM III dan PIM IV telah terlaksana dengan cukup baik dengan adanya metode dan kurikulum terbaru dari Lembaga Administrasi Negara yang dipandang lebih progresif dalam membekali para pejabat atau calon pejabat yang berstatus sebagai peserta diklat dengan wawasan, pengetahuan dan berbagai keterampilan dalam menunjang pekerjaan para pejabat atau calon pejabat pemerintahan sesuai dengan profesi dan uraian tugas jabatanya pada masing-masing instansi tempat mereka mengabdi .

2. Terdapat berberapa faktor yang menjadi kendala selama proses berlangsungnya diklat Struktural diantaranya ialah kurang memadainya sarana dan prasarana pendukung serta yang terpenting adalah Kualitas dan jumlah tenaga widyaiswara yangb masih sangat terbatas adapun penyebabnya adalah kurangnya komitmen serta dukungan Pemerintah Daerah melalui alokasi dana yang proporsional.

3. Upaya yang dilakukan Badan Kepegawaian dan Diklat Kabupaten Sorong meliputi upaya yang bersifat Prosedur dann teknis. Upaya Prosedural berkaitan dengan proses input dan output program kerja Badan Kepegawaian dan Diklat sementara Upaya tekniks berkaitan dengan kebutuhan-kebutuhan terkait dengan penyelenggaraan program kerja Sereta kegiatan Kediklatan.

\section{DAFTAR PUSTAKA}

Ambar.2009.Manajemen Sumber Daya Manusia. .Graha Ilmu. Jakarta.

Anwar Prabu Mangkunegara.2009. Manajeman Sumber Daya Manusia. Rosda Karya. Bandung. 
Akib, Haidar \& Tarigan, Antonius. 2008, Artikulasi Konsep Implementasi Kebijakan: Perspektif, Model Dan Kriteria Pengukurannya, Jurnal Kebijakan Publik. Jakarta.

Arikunto, Suharsimi. 2006. Prosedur Penelitian Suatu Pendekatan Praktik. Rineka Cipta. Jakarta.

Bynard, Petrus A, 2005, Policy Implementation: Lessons For Service Delivery. Papper of Annual Roundtable Conferens. Zambia.

Edward III, George C (edited), 1984, Public PolicyImplementing, Jai Press Inc. London-England.

Efferin, Sujoko, dkk. 2004. Metode Penelitian Untuk Akuntansi. Bayu Media Publishing. Malang.

Jones, Charles O. 1984, Pengantar Kebijakan Publik. Raja Grafindo Persada. Jakarta.

Grindel. 1980. Politics and Policy Implementatition in The Third World.Pricentone,.University Press. Princetone.

Goggin, Malcolm L et a.1990. Implementation, Theory and Practice: Toward a Third Generation, Scott Foresmanand Company. USA.

Mazmanian, Daniel A and Paul A. Sabatier. 1983.Implementation and Public Policy, Scott Foresmanand Company. USA.

Notoatmojo, Soekijo. 2009. Pengembangan Sumber Daya Manusia. Rineka Cipta. Jakarta.

Peraturan KLAN No. 15 Tahun 2011 Tentang Pedoman Pembinaan
Penyelenggaraan Pendidikan Dan Pelatihan Fungsional.

Poerwandari. 2007. Pendekatan Kualitatif Untuk Penelitian Prilaku. LPSP3 UI. Jakarta.

PP No. 101 Tahun 2000 Tentang Pendidikan dan Pletaihan Jabatan Pegawai Negeri.

Purwanto, Sulistiyastuti, 2015, Implementasi Kebijakan Publik,. Ramadan. Bandung.

Purwanto, Erwan Agus, 2004. Revitalisasi Studi Implementasi Kebijakan Publik, Jurnal Kebijakan dan Administrasi Publik, Magister Administrasi Publik, Yogyakarta.

R. Arif. 2009. Memahami Pendidikan dan Ilmu Pendidikan. Mediatama. Yogyakarta.

Ripley, Rendal B. and Grace A. Franklin. 1986. PolicyImplementation and Bureaucracy. second edition, theDorsey Press. Chicago-Illionis.

Sabatier, Paul. 1986. "Top down and Bottom up Approaches to Implementation Research" Journal of PublicPolicy 6. University Press. Princetone

Sinambela, Lijian Poltak, 2006. Reformasi Pelayanan Publik, Teori, Kebijakan dan

Implementasi. Bumi Aksara. Bandung

Siswanto, Sastrohadiwiryo, DR, 2001, Manajemen Tenaga Kerja Indonesia, PT. Bumu Aksara. Jakarta.

Sinambela, Lijian Poltak, 2012. Kinerja Pegawai, (TeoriPengukuran dan Implikasi), Graha Ilmu. Yogyakarta. 
Siagian, Sondang P.1989. Teori dan Praktek Kepemimpinan. Rineka Cipta. Jakarta.

Sugiono. 2012. Metrode Penelitian Pendidikan : Pendekatam Kuantitatif, Kualitatif dan R\&D. Alfabeta. Bandung.

Suradinata Ermaya. 2003, Manajemen Sumber Daya Manusia, Ramadan Bandung.

Tachjan. (2006). Implementasi Kebijakan Publik. AIPI. Bandung.

Umar, Husein. 1999. Riset Strategi Perusahaan. Gramedia Pustaka Utama. Jakarta

Undang-Undang No 5 Tahun 2014 Tentang Aparatur Sipil Negara.

Winarno, Budi. 2002. Teori dan Proses Kebijakan Publik,

Media Pressindo. Yogyakarta. 